\title{
Socio-Legal Perspectives on Immigration and Refugee Law in Russia
}

There were still heaps of snow on the sides of the pavement when I arrived in Moscow for fieldwork. At the NGO where I was to start my observations I was welcomed by Muiz, an asylum seeker from Syria, who was staffing the reception desk. He spoke perfect Russian, and he invited me to come in and showed me to the lawyers' office. There was a long queue spanning the adjacent waiting room and the corridor; the lawyers were busy seeing to their clients behind the closed doors. I did not dare enter, so I joined the queue. I did not realize then that standing in line would become the leitmotiv of my field research on the everyday 
experiences of the law, human rights and access to justice for migrants and refugees in Russia.

'Devushka podozhdite' ('Girl, do wait, please') are some of the first words I heard, later, in the hallways of the Federal Migration Service (FMS) local field offices, where I accompanied migrants to submit asylum claims, applications for work permits or to make enquiries about the outcome of an administrative review against their entry bar. There was always a very high chance of hearing 'Devushka podozhdite' when attempting to enter the office of the clerk of the court, where I joined migrants submitting appeals in their cases, reviewing their case files or enquiring about final judgments. 'Podozhdite v koridore' ('Do wait in the corridor, please') was also part of the unwritten code of conduct ahead of the various court hearings, known to all parties of the legal proceedings: migrants, asylum seekers, their lawyers, court interpreters, even the FMS legal representatives. 'Devushka podozhdite' I would also hear at the entrance to other institutions connected with migration in Moscow, where I attempted to gather data or conduct interviews for my fieldwork. Except, as it turned out, in this NGO.

The news about my arrival must have spread quickly among the staff. At one point, one firm hand of Elena, the vice-chairwoman of the NGO, grabbed my shoulder while the other opened the door to the lawyers' office. Her trusting and kind eyes seemed to say: 'Why are you waiting, silly? Just enter.' She announced me to the lawyers and made me sit on the chair in one corner of the office. The room was fairly small and staffed with three lawyers consulting their clients asylum seekers from all over the world (mainly East and West Africa, Central 
Asia, the Middle East and Ukraine) and migrant workers, primarily from Central Asian and other former Soviet Union republics. I had to sit so close to one of the lawyers that even taking out my notebook seemed intrusive to the dynamics of the intimate relations unfolding in front of my eyes in the consultation room. On this first day, I only observed. Later, I managed to make myself less conspicuous, and perhaps even helpful by volunteering at the photocopier, interpreting or running small office errands for the lawyers.

It is therefore with the trust showed to me by the NGO staff that this book adventure began...

\section{Socio-Legal Perspectives on Migration}

Russia is in the top five migrants receiving countries worldwide (after the United States, Saudi Arabia and Germany), with 11.6 million foreign-born people currently residing in its territory (UNPD 2017). Sergey Abashin supplements this number with another 11 million migrants who live in Russia de facto permanently but do not apply for a residence permit or citizenship (Abashin 2017: 16; see also Schenk 2018: 1). They have come to Russia primarily from the post-Soviet countries in Central Asia (Uzbekistan, Tajikistan, Kyrgyzstan) and other CIS states.1 ${ }^{1}$ Seasonal and undocumented economic migration was part of the Soviet reality, but this reached new levels and took different forms after the break-up of the Soviet Union (Pilkington 1998). Unrestricted cross-border

\footnotetext{
${ }^{1}$ Formed in 1991, the CIS - Commonwealth of Independent States consists of 12 of the former republics of the Soviet Union (Armenia, Azerbaijan, Belarus, Georgia, Kazakhstan, Kyrgyzstan, Moldova, Russia, Tajikistan, Turkmenistan, Ukraine and Uzbekistan).
} 
movements between Russia and its 'near-abroad' countries of Central Asia facilitated the migration of desperate people leaving their economically destitute and often politically repressive home countries in search of survival. Migrants account for about 3-4 per cent of the employed population in Russia (if undocumented migrants are included, this share grows to about 7 per cent) (Denisenko and Varshavskaya 2013: 2; Vakulenko and Leukhin 2017: 84). These workers are mostly engaged in the construction industry, agriculture, trade and services. Every large state-funded project, such as building venues and infrastructure necessary for Russia to host the 2014 Winter Olympic Games in Sochi or the 2018 World Cup, is reliant on the extensive employment of migrants. Labour migrants form a group diverse across many variables, including race, ethnicity, religion, legal status and acquisition of Russian citizenship. The migratory movements between Central Asia and Russia have, by now, become intrinsically linked to wider processes of social change and development in the region (Castles 2010; de Haas 2010; 2012). Not only individual families, but whole communities 'left behind' are often dependent on remittances sent by migrants (Buckley and Hofmann 2012). Kyrgyz Republic and Tajikistan in 2016 ranked second and fourth in the list of the main remittance-dependent countries worldwide - with personal money transfers constituting 30.4 and 26.9 per cent of their respective GDPs (World Bank 2016). Remittances sent by migrants constitute an inseparable part of family budgets; this money is primarily used for consumption (daily expenses, house repairs) and small investments, mainly in livestock (Aitieva 2015). Moving to Russia to find work became a culturally ingrained rite of passage towards adulthood for many young Kyrgyz, Tajik and 
Uzbek migrants (see, e.g. Maier 2014) - a testimony to a specific 'migration culture' developing in the region (Buckley et al. 2008; Bahovadinova 2016). Russia, by virtue of being an important global political player, has also been attracting a steady stream of refugees: from Afghanistan, Iraq, Central Asia and, more recently, Syria, the Middle East, Africa and Eastern Ukraine.

In the area of migration studies, the existing scholarship provides evidence of immigrants' and refugees' incorporation and responses to specific host-country laws and policies, but this is predominantly limited to the North American or Western European experiences (Portes and Bach 1985; Portes and Zhou 1993; Hagan 1994; Alba and Nee 1997; Coutin 1998, 2000, 2002; Hagan 1998; Menị́var 2000, 2006, 2014a, 2014b; Hein and Beger 2001a, 2001b; de Genova 2004; Kubal 2009, 2012, 2013, 2014; Menị́var and Abrego 2012; Salcido and Menị́var 2012). Russia remains, in this respect, a true terra incognita (for recent notable exceptions see Reeves (2013, 2015); Davé (2014); Light (2016); Agadjanian et al. (2017); Buckley (2018); Schenk (2018)). Modern Russia (beyond the immediate post-Soviet period) is also largely absent or barely mentioned in global surveys about migration (Cohen 1995; Castles et al. 2014; Hollifield et al. 2014). By situating the Russian case in a comparative perspective with the United States and other major migrant-receiving jurisdictions in Europe, this book demonstrates how the evolution of Russian immigration law in 'the everyday work of producing, defining and precluding both movement and connection' (Coutin et al. 2002) follows a well-established logic of more global trends of migration governance. Russia's fairly unexplored though complex legal environment and visa-free regime with near-abroad countries are also fruitful 
avenues through which to interrogate broader questions about the growing salience of 'mixed' flows of people (Van Hear 2004; Van Hear et al. 2009) and the persistent separation of the analytical categories of 'migrant workers' and 'refugees', even though the empirical boundaries between them have long been recognized as continuously porous (Kay and Miles 1988; Karatani 2005; Long 2013; Kubal 2016a). Comparing the outcomes of my ethnographic study in Russia with data collected earlier from Western countries and the literature developed there, this book questions whether what happens to migrants and refugees in Russia is as much in contrast with the experiences of migrants and refugees in Europe and America as many observers tend to assume.

Russia's immigration policy and immigration law have recently started attracting increased academic attention (Riazantsev 2007; Ivakhnyuk 2009; Reeves 2013, 2015, 2016; Davé 2014; Ivakhniuk 2014, 2015; Malakhov 2014; Light 2016; Abashin 2017; Buckley 2018; Schenk 2018). While the immigration controls in the USSR were distinct, in the sense that the state over-ambitiously aimed to fully regularize internal migration by integrating it into a system of administrative controls and localized social policies dependent upon residence registration (Light 2012), modern Russia seems rather to subscribe to a more global trend towards 'irregularization' and deportability, leading to a proliferation of insecure migration statuses (Kubal 2016b; Schenk 2018). At the same time, researchers, reporters and human rights activists have extensively documented the difficult living and working conditions of labour migrants in Russia (Yudina 2005; Greenberg 2007; Doolotkeldieva 2008; Ruget and Usmanalieva 2008, 2010; Round and Kuznetsova 2016; Urinboyev 2016). The 
list of ways in which their human rights are abused is long: discrimination at work, such as routinely being denied wages; failure to provide required contracts; unsafe working conditions (Human Rights Watch 2009); racial profiling for document checks when using public transport (Open Society Institute 2006); extortion of bribes by the police (Chupik 2015); and other extralegal strategies aimed at controlling their movements (Light 2010, 2012;

Kondakov 2017). Judged by the recent reporting of human rights organizations, in some cases economic migration in Russia is turning into modern slavery (Round and Kuznetsova 2016; Buckley 2018). These accounts intersect with some long-established assumptions about Russia's exceptionalism also in the broader legal sphere: lack of the rule of law, corruption and legal nihilism (Ledeneva 1998, 2006, 2008; Kurkchiyan 2003, 2009; McAulley et al. 2006). Much of the academic literature, analytical reports, mass media and even common wisdom suggest that the justice system in Russia is unreliable. It does not provide equal access to justice, it does not treat its litigants fairly, law enforcement is fortuitous and 'telephone law' still prevail in different court settings (Pastukhov 2002; Solomon 2005; Transparency International 2007; Sakwa 2009, 2010).

But perhaps the full picture is not so uniform and bleak? The main idea behind this book was to find out how the immigration and refugee laws work 'in action' in Russia. How are they experienced in everyday life by the different actors involved in the migration process? Can migrants and refugees access justice and stand for their rights in Russia? How and when? Under what conditions? What is the role of human rights and migration lawyers in mediating 
access to justice for migrants and refugees? How do Russian judges decide cases involving migrants and asylum seekers, and with what consequences for the litigants involved? Are these experiences so much different to what is happening in other major migrant-receiving countries, mainly the United States and those of Europe?

\section{Researching Immigration and Refugee Laws in Everyday Life}

I went to Russia guided by these (and other) questions, with an open mind and an open heart. In my attempted thick description (Geertz, 1975, 1983) of Russian immigration and refugee legal regimes I wanted to document the different processes, experiences, encounters, pieces of legislation, legal texts, court cases and forms of discourse that make up the lived experiences of the law. In this book, I therefore trace and map the experiences of migrants, immigration lawyers, asylum seekers, refugees, Russian judges and FMS officers. These actors often speak with completely different voices, profess different ideologies and hold diametrically opposite worldviews; however, the thing they share in common is their centrality to understanding migration processes in Russia.

The turn to everyday life in the study of immigrants, refugees and state law enforcement officials has long been observed in socio-legal studies in 'Western' academic writing. ${ }^{2}$ For example, Roberto de Genova examined

\footnotetext{
2 I use Western as a heuristic (meaning liberal-democratic) to enable comparison with other main migrant-receiving countries - the United States, United Kingdom and Western European countries - and the scholarship developed there.
} 
extensively the everyday experiences of migrants living under conditions of deportability in the United States (de Genova 2002). Nando Sigona focused on lived experiences of the stigma of illegality in the United Kingdom (Sigona 2012). In my earlier work I looked at how immigrants experience the criminalization of immigration law under different European jurisdictions (Kubal 2014). These pieces of research were founded upon systematic data collection referred to among methodologists as in-depth qualitative and ethnographic fieldwork: firsthand observations supported by intensive, carefully planned interviews with a number of crucial actors. Conversely, much of the analogical research in Russia still suffers from quantitative bias - a conventional approach fixated on quantitative indices and large-scale surveys giving the impression of 'objectivity' but no voice to those whose lives are shaped by the law (see Sarat and Kearns (1995) for a noteworthy and recent exception; see also Reeves (2013) and Hendley (2017)).

I position this book vis-à-vis much of the scholarship solely referring to legal and social quantitative indices (e.g. the World Bank's Rule of Law index), arguing for an interpretative, in-depth understanding of the various social processes on the ground. Many of the indices, ceteris paribus, create an illusion of comparability, as in the process of data collection inconsistent evidence is being used. The 'expert' reports that feed into these indices often, due to the lack of reliable empirical data (how to measure corruption in courts?), operationalize the various indicators on the bases of 'general knowledge' and media coverage. This results in much of the research becoming an unsatisfactory litany of what everybody already knows about Russia, resulting in explanations that strike 
familiar cords with conspiracies already known to many (Umberto Eco would say this is what makes them believable) - endemic corruption, deeply entrenched patrimonial state, presided over by Putin's steely, unflinching gaze. I think much of the scholarship that reproduces negative myths about Russia is still rooted in the Cold War Sovietology (and its daughter, Kremlinology), which as the 'scientific' study of politics and policies of the Soviet Union, continue to dictate the legitimate ways of 'doing research on Russia'. Russia is orientalized dark, secretive, sensual and corrupt (for a variation of this argument, see Hendley (2017: 222)).

In order not to reproduce the stereotypes and negative myths about Russia, I conducted my fieldwork in a variety of settings triangulating between different - sometimes conflicting - sources of information. I spent over five months in Russia in 2014, conducted a couple of shorter trips in 2013, and kept in close contact with most of my core informants (both legal professionals and lay people) upon my return.

First, I conducted participatory, long-term observations in a number of Russian NGOs, legal aid clinics and organizations that help immigrants and refugees in Russia with their legal problems regarding status determination, residence and access to the labour market. The lawyers, social workers and members of these organizations also represent immigrants and refugees in courts, in disputes with employers or with the state immigration agencies like the FMS. Over several months, I volunteered in these organizations in a variety of roles. I sometimes worked as an office clerk or an interpreter from English to Russian during the interviews with refugees from the Middle East or Anglophone 
Africa. On other days, I shadowed the lawyers when they were representing the clients of those NGOs in domestic courts and assisted with writing submissions to the European Court of Human Rights (ECtHR) in more serious cases. Throughout these several months, I observed the interactions between the lawyers, employees of the NGOs and their clients. These daily observations, supplemented by in-depth interviews with a selected number of representatives of the NGOs, migrant organizations, legal professionals and lawyers, ${ }^{3}$ were informative about the grass-roots level of implementation of immigration law and its everyday experiences - the 'nuts and bolts' of the refugee status determination procedure in Russia, and its current trends and directions. These observations satisfied my curiosity as to the role the above-mentioned institutions play in mediating immigrants' and refugees' access to justice in Russia and the experiences of handling claims and complaints, their outcomes and consequences.

Second, I often accompanied migrants and refugees - the clients of these NGOs - during their reluctant visits to state immigration agencies like the FMS, to submit an application for a refugee status, renew their temporary asylum, attend an interview as part of the status determination procedure or to clarify the questions regarding one's residence permit in Russia. These were usually wholeday or half-day trips due to the leitmotiv of waiting, which I alluded to in the opening vignette. Waiting in line, sitting in the corridor proved, however, conducive to gathering rich empirical data: I could observe the dynamics between the FMS officers and the migrants, asylum seekers and other FMS

\footnotetext{
${ }^{3}$ Overall, I conducted 50 interviews. For the full list of informants (anonymized), see Appendix 1.
} 
officers, as well as ancillary staff - clerks and interpreters. Migrants, whom I accompanied, were usually my guides to these different interactions; they painstakingly explained to me who was who, who was important, with whom we should talk, and whom we should ideally avoid. During these hours in the corridors of the FMS offices, I also met with other migrants and asylum seekers, learned about their stories, migratory journeys, families and plans for the future. They often shared with me the intricate details of their individual petitions to the FMS. Upon entering the concrete FMS offices, I could observe the interactions between the FMS officers and their clients, the modes of assessment of their cases, the type of advice given and potential outcomes. Sometimes I was told I was not welcome, but more often than not the FMS officers treated me as a curious distraction to their daily business, and were largely willing to engage and talk with me.

Third, I conducted a three-month ethnographic study in a sample of lowlevel courts and courts of appeal in Moscow (district courts, Moscow City court and Greater Moscow oblast court). This was informative about the nature of cases when migrants, refugees or their representatives mobilized the law either in challenging the alleged immigration law violations resulting in administrative removal (expulsion) orders, appealing the decisions of the FMS regarding their refugee status or complaining about unauthorized issuance of the entry bar by the specific FMS territorial unit. The observations of the interactions in the courtroom gave first-hand information on the type and volume of immigration law cases, how the migrants and refugees were treated in court and about their ability to defend themselves. The actual observations of the different 
cases were closely linked to the hours spent in the halls of justice awaiting the hearings. That again provided an opportunity to engage and build rapport with the different actors of the legal process - immigration lawyers, migrantdefendants and FMS legal representatives - who were also waiting in line for the hearings to commence. Through informal conversations with judges, I have learned how the system views migrant-litigants and how it responds to their grievances.

Fourth, I analysed a number of judgments from the Russian domestic courts at different levels of jurisdiction in immigration and refugee cases. I have obtained the written texts in a number of ways: mainly I received copies of the judgments from the immigration lawyers; sometimes I accessed the judgments directly as they were available on the courts' websites. They originate not only from the five months of 2014 when I was actually in Russia, but cover the years 2014-2018, when I continued to maintain electronic or telephone contact with the lawyers. The analysis of the different judgments provided the crucial empirical material to support my argument about the 'case file' versus the 'human rights' logics that asymmetrically unfold in immigration and refugee cases in Russia (see Kubal 2018). Out of a collection of around 100 judgments, 35 refer to human rights. ${ }^{4}$ While this picture is therefore by no means generalizable, it nevertheless offers important qualitative and discursive insights into the use

\footnotetext{
${ }^{4}$ As I was interested in the arguments around human rights, I have removed from the text all information that could identify the defendant, their legal representative, the judge or the geographical area where the court was located. For analytical reasons, however, I still present the facts of the case, and mention the level of the court that rendered a particular judgment. This information, if cited, was anonymized in the text.
} 
(and absence) of human rights arguments in immigration and refugee law cases. I accompanied the textual analysis of domestic court judgments with collecting and reading a number of ECtHR judgments against Russia in immigration and refugee law cases. These judgments mainly stem from the Garabayevgroup of cases, 5 which spans more than 80 cases decided by the Strasbourg Court between 2007 and 2018 .

Finally, my regular observations in the NGOs, FMS offices, courts and the analyses of written court judgments were supported by in-depth interviews with migrants themselves, sometimes in more formal settings, sometimes less structured and less formal (e.g. at social gatherings or at homes). This book thereby also strives to give a voice to those whose lives are shaped by the law, and discusses immigrants' and refugees' everyday life experiences of immigration and/or refugee law, the intricate strategies of living under its shadow, but also the practices of challenging it. The interviews included in this book reach beyond the straightforward evidence and legal argumentation of a case and inquire into the background of the problem at hand, the various assumptions and expectations of the parties involved, and the personal hopes and fears of each respondent. This is not to say that I discard the quantitative evidence; I rely on the statistical and macro-trends as the first step of the enquiry, with each of the chapters extending it with in-depth qualitative, ethnographic explanations and analysis.

In the pages of this book, the reader will get to know the story of a Kurdish-Syrian family from Iraq with four young children, who spent nearly two

\footnotetext{
${ }^{5}$ For the description and analysis of the Garabayev group of cases before the ECtHR, see Chapter 7.
} 
months in the transit zone of Sheremetyevo Airport as the Russian authorities decided to prioritize criminal prosecution of their alleged illegal entry over processing their asylum claims. The intervention of the charismatic chairwoman of the legal NGO and the work of her lawyers led to the family being ultimately allowed into Russia and granted temporary asylum. The reader will learn the story of Akmal, a taxi driver turned construction manager from Uzbekistan, who despite residing in Moscow for over ten years found himself deportable with a three-year entry bar due to minor traffic violations. I share the story of Bahrom, an asylum seeker from Uzbekistan, whom the FMS refused to recognize as a refugee and insisted he should legalize his stay in Russia as a migrant worker. Discussing the use of human rights law in Russian domestic courts, I weave in the narratives of two Syrian refugees and one Palestinian, whose claims to international protection were initially denied by Russian domestic courts until the decision of the ECtHR. 6 The Strasbourg Court found their planned administrative removal to Syria to be in breach of their right to life, and the men were ultimately granted temporary asylum in Russia. Finally, the narratives of Myriam and her husband, refugees from Tajikistan and applicants before the ECtHR accused of membership in a banned Muslim allegedly 'extremist' organization - Hizb ut-Tahrir 7 - guide the reader through myriad questions that cannot usually be answered with reference to the written court judgments. Their personal, often intimate, experiences contained in these narratives cast more

\footnotetext{
${ }^{6}$ LM and Others v. Russia (nos 40081/14, 40088/14 and 40127/14, judgment of 15 October 2015) - concerning the removal of Syrian nationals for ordinary immigration offences in the midst of the civil war in Syria (2011ongoing), the first such case in Europe (see also Kubal 2016a).

${ }^{7}$ For an explanation of Hizb ut-Tahrir as an organization, see Chapter 7.
} 
light on the meanings, ideas and understandings behind those legal cases. They transcend the narrow legal parameters of the case and provide a window to the broader social context within which the immigration and refugee laws are firmly embedded. These and other stories contained in this book show how important it is to complement the observations of cases and reading of the judgments with the voices and experiences of people themselves in order to arrive at a bigger picture as to whether human rights are for migrants. In order to protect the anonymity of my respondents I have changed their names, and sometimes details of their stories by weaving through them some of the recurring themes and experiences appearing within other interviewees' personal narratives. All this was done so that my respondents could not be identified in real life.

\section{What Is this Book About?}

This book offers an ethnography of access to justice and the realization of human rights for migrants and refugees in Russia. It focuses on the everyday experiences of immigration and refugee laws and how these different legal frameworks work 'in action' in Russia (Pound 1910). This investigation is sociological, starting from a premise that the situation on the ground is much more complex than the law 'in the books' assumes, as it is mediated by people's varied positionalities within the justice system. The legal experiences of every kind of person - whether an immigration, refugee or human rights lawyer (Chapter 3); an immigrant or a refugee (Chapters 4 and 7); an FMS official (Chapters 4 and $\underline{5}$ ); a Russian domestic judge or a judge at the ECtHR (Chapters $\underline{5}, \underline{6}$ and $\underline{7})$ - is informed by a multiplicity of structural variables such as age, 
gender, education and ethnicity. Their experiences of the legal system are mediated by various contexts, personal histories, beliefs and ideologies that influence social dynamics (sometimes leading to social conflicts). All these factors and different positionalities intersect, so they need to be dissected with care (McCall 2005).

My primary focus in gathering material for this book was on people, their stories and experiences. Researching something as complex, intricate and everchanging as immigration and refugee legislation in Russia, especially given the long tradition of Russian legal formalism (Kurkchiyan 2009; Kahn 2010; Hendley 2017), one could easily get distracted by the legal changes, amendments and different interpretation of written rules, and lose sight of the people who operate within (and outside) this system. I did not go to Russia with a pre-determined list of legal acts, paragraphs and ordinances that I wanted to trace 'in action'. My socio-legal approach was rather informed by the 'bottom-up' logic of ethnography. I observed the everyday experiences of immigration law as they unfolded in the lives of the different actors to see what issues come to the fore as most relevant and analytically significant for defining access to justice and the realization of human rights for migrants and refugees in Russia. It is only after collecting the empirical material that I went back to the law in its textual, blackletter sense. Even though this book starts with an overview of the legal environment to provide the context, clarify certain legal points and equip the reader with the necessary legal background to comfortably approach the subsequent chapters, it is important to mention that this legal overview was compiled at the end of the writing process. 
Chapters $3-\underline{7}$ constitute the main body of this book. Each of these is a selfcontained ethnographic case study of an aspect, element or constituent part of how the immigration and refugee laws are experienced in everyday life in Russia.

I begin Chapter 3 by introducing some of the main actors responsible for access to justice for migrants and refugees. There are many conceptualizations of access to justice in the socio-legal literature. The broader understanding combines 'the complexity of procedural rules, the transparency of the law, and the overall efficiency of the court system' (Hendley 2017: 182) alongside the availability of legal expertise. While Russia is considered to have fairly straightforward access to civil justice as far as Russian litigants are concerned (Hendley 2017: 182), this might not necessarily be true for migrants or refugees. Their access to justice or the status determination procedure in Russia (as elsewhere in the world) is complicated by a number of barriers, including linguistic ones (Burtina et al. 2015). Therefore, the figure of a legal representative - an immigration, refugee or human rights lawyer - is crucial to interrogate the full picture of access to justice. Given that my fieldwork commenced in the legal NGO, I first focus on the immigration, refugee and human rights lawyers in Russia and position them analytically within the broader sociolegal debates on cause-lawyering in the United States, Western Europe, IsraelPalestine and South Africa (Bisharat 1998; Menkel-Meadow 1998; Sarat and Scheingold 1998a, 1998b, 2001a, 2006; Appelqvist 2000; Coutin 2001; Hilbink 2004; Scheingold and Sarat 2004; Krishnan 2006; Boukalas 2013). I argue that Russian cause-lawyering in the areas of migration and refugee law has certain specific features that distinguish it from 'mainstream' cause-lawyering - the 
latter focusing on impact and strategic litigation, changing laws and reforming the legal system. Russian immigration and human rights lawyers have something different 'to believe in' (Scheingold and Sarat 2004) that characterizes their specific style of cause-lawyering: humanism and care for the individual client. They would often abandon important legal victories or setting legal precedents for the sake of saving individual clients, attending to the specific needs of a refugee or asylum seeker in front of them. Some scholars question whether this style of lawyering - without transforming the status quo or prevailing arrangements of power but 'accepting a detrimental precedent or rule of the client can be made to "fit" within its parameters' (Hilbink 2004: 687) - should even be considered as part of the cause-lawyering movement (Bisharat 1998; Shamir and Chinski 1998; Sterett 1998; Haijar 2001). I argue that it should, given the change in the status quo in the lives of the represented individuals (Porter 1998) and strong connection between law and morality (Sarat and Scheingold 1998a) exhibited by the lawyers. In this book, I conceptualize this as causelawyering 'a rebours' (or cause-lawyering with the grain).

Having introduced the lawyers in Chapter 3, I next focus on their clients and examine migrants' perspectives on the everyday grass-roots level of implementation of immigration law through the case study of the recent entry bar legislation (Chapter 4). From 2013, a three-year entry bar (zapret na v'ezd) has been issued in Russia to migrants with a record of two or more administrative offences. What counts as an administrative offence may be a simple traffic offence such as driving without a seatbelt or crossing the street in the wrong place. I introduce the everyday experiences of living with an entry bar 
through the story of Akmal, a migrant worker from Uzbekistan, who has been residing in Moscow for many years with his young family only to find himself deportable (and without much possibility of regularizing his status) due to these new legal changes. This chapter further analytically positions the socio-legal characteristics of zapret na v'ezd in a more global, comparative perspective, visà-vis the legal developments in the areas of deportation and removal in the United States and the United Kingdom. The entry bar in Russia follows a wellestablished logic of an increased reliance on deportability as a form of post-entry control of the migrant population (Morawetz 1998; Kanstroom 2000). The comparative analysis also invites a deeper reflection about the consequences of the civil/criminal labels in migration law. Although formally within the remit of administrative law, zapret na $v^{\prime} e z d$, if analysed from the perspective of severity and impact on migrants' lives, actually constitutes a quasi-criminal sanction, a form of punishment. Ultimately, I argue that the entry bar could best be understood as a form of deportation, exclusion from legality, albeit a surreptitious one: demonstrating the possibility of deportation, the possibility of being removed from the space of the nation-state which constitutes a specific form of contemporary migration governance (de Genova 2002; de Genova and Peutz 2010).

The inspiration behind the following two chapters was born in the Moscow courtrooms while observing cases involving migrant-litigants. These cases pertained to common administrative violations of the immigration regime expressed by two specific articles of the Code of Administrative Offences: art. 18.8 (Part 3) and art. 18.10 (Part 2) - lack of a residence registration or a valid 
work permit, respectively. The defendants in these cases were migrant workers from Central Asia (Tajikistan, Uzbekistan and Kyrgyzstan) and other post-Soviet republics (Ukraine, Azerbaijan and Georgia). My observations revealed that the great majority of these cases were adjudicated according to the so-called paper or case file model (see Kubal 2018). Judges arrived at their decisions on the bases of the written evidence presented in front of them and contained in the case file. During the trial, they did not engage in questioning the defendants about the circumstances or their version of the events to build up a full picture of the facts of the case. Instead, they relied on the seemingly unquestionable formal evidence produced by the FMS: protocols from immigration raids, affidavits by the defendants and reports and photographic evidence taken by FMS officers. Ultimately, the case file - not the defendants, the witnesses or even the judges occupied centre-stage in these immigration proceedings. These observations made me further interrogate the role of the case file in the everyday life of immigration law: How was it put together? By whom? Under what circumstances? At what stage of the process did the case file acquire the epistemological function of translating the empirical reality for the purpose of the legal proceedings? What was the role of the different documents contained in the case file (dated envelopes, official stamps and handwritten signatures)?

Addressing these questions, tracing the genesis and the life of the case file in Chapter 5, took me back to the immigration and refugee lawyers' offices and to the offices of the FMS. There, I met lawyers who had meticulous case law libraries and categorized their clients through the thickness of their individual case files. I met with FMS officers who had it in their power to decide which case 
files were strong in documentary evidence to warrant further attention. I also consulted broader comparative, socio-legal and anthropological literature on the documentary practices and culture of materiality in legal proceedings (Riles 1999; Tuitt 2005; Scheffer 2007; Levi and Valverde 2008; Latour 2009; van Oorschot 2014; van Oorschot and Schinkel 2015), especially the capacity of the case file 'to make things come into being' (Frohmann 2008: 166; Vismann 2008; Hull 2012). Ultimately, this chapter contends that while all legal case files have the epistemic capacity to mediate the empirical reality for the purpose of the trial - 'to mediate between the laws and specific oral utterances' (Vismann 2008: 9) under some jurisdictions the paper files construct reality more actively than in others, beyond a mere legal translation. This active production of reality - or hyperbolic epistemic function - folding of complex, interrupted and messy events into a linear narrative, happens in Russia in response to legal formalism and literal reading of the law. 'Quod non est in actis, non est in mundo' - What is not kept in the case file does not exist (see also Kahn 2010). The truth or falsity of documentary claims is often beside the point to the different individuals involved in the legal proceedings, and the formal-looking documents serve as grounds for official actions and decisions even when they can be shown to be ultimately fake.

While case file logic dominates most of the decision-making in immigration and refugee cases in Russian domestic courts, it does not mean that its rule is supreme. In certain exceptional circumstances, the judges rely on and invoke different sets of arguments - referring to Russian obligations under human rights law. Russia signed the European Convention of Human Rights 
(ECHR) in 1996 and ratified it in 1998. While it is a matter of open debate whether the human rights safeguards contained in the ECHR and the Strasbourg Court jurisprudence are suitably specific to effectively protect the rights of migrants (Dembour and Kelly 2011; Dembour 2015; Costello 2016), certain provisions of the ECHR are directly relied upon by domestic courts in Russia in immigration, asylum and refugee law cases. This is when consideration is given to the fact that migrants or asylum seekers cannot be deported to a place where they might find themselves at risk of torture, inhuman and degrading treatment (art. 3 ECHR) or when the return may mean a grave risk to their lives (art. 2 ECHR). Along the same lines, the judge may give due recognition to the fact that a deportable migrant has close family members in Russia, and that the imminent deportation would violate their right to private and family life (art. 8 ECHR). Other human rights arguments were invoked when setting the time limits of detention pending administrative removal (or detention pending extradition) in order to protect the human right to liberty (art. 5 ECHR).

In order to develop my argument about the human rights logic in Chapter $\underline{6}$, I turned to specific court judgments from various domestic courts of general jurisdiction: low-level district courts, regional (and city) courts, the Supreme Court of Russia, and supreme courts of the different republics (subjects) of the Russian Federation. I also consulted certain judgments of the Russian Constitutional Court in St. Petersburg. My sampling of judgments for this chapter was purposeful; I selected judgments that made some reference to human rights to discern the broader practices and understandings: if Russian domestic judges did invoke human rights, how exactly did they do it? Working with the various 
textual documents helped me construct a typology of how the different human rights arguments were raised and invoked. The application of the human rights logic by the domestic judges was not straightforward, and there was a significant variation in how the courts ultimately relied on it. It ranged from: (1) an explicit application and recognition of specific human rights claims (with reference to the ECHR and other international human rights instruments); (2) implicit reliance on human rights claims (with reference to domestic legal provisions, e.g. the Russian Constitution); (3) affirmation of the ECtHR jurisprudence; and, finally (4) outright rejection of human rights arguments (if and when these were raised by the defence during the proceedings).

The picture of the human rights application in immigration and refugee cases in Russia that emerges from the written judgments is, however, incomplete. The formal court judgments do not allow the reader to get to know the applicants before the court, as their personal experiences are often reduced to a few words under the heading 'facts of the case'. Who are the humans behind these and other migration cases in Russia? What are theirstories and their experiences?

The last substantive chapter, Chapter 7, therefore gives voice to the migrants, asylum seekers and refugees themselves, and serves as a platform to let them assert their side of the story (Delgado 1996; Natapoff 2005; Levit 2010; Di Donato 2011; Fielding 2013). These narratives, aside from their purely expressive role, also serve broader analytical functions. First, they demonstrate the epistemological limits of the different courts - both at domestic and international levels - in capturing and defining the various human rights 
violations. Addressing this question cannot really take place without bringing to light migrants'lived experiences of inhuman and degrading treatment, migrants' experiences of detention as deprivation of liberty, migrants'understandings of family life. Second, these stories act as 'sites of resistance' (Ewick and Silbey 2003) by demonstrating how resistance to formal law can also be achieved through telling an alternative story that disrupts and exceeds the textual confinement of the facts of the case before the court. Telling a story 'on their own terms', telling 'what really happened' constitutes a challenge to the legally affirmed facts and sequences of events. Finally, these narratives are important as they offer a rich, contextual and ethnographic illustration to an intricate dialogue between Russian immigration authorities, domestic courts and the Strasbourg Court. They supply a number of clues that help to trace the adaptability of Russian immigration law to the ECtHR jurisprudence, and interrogate the broader relationship between Russia and the ECtHR. 